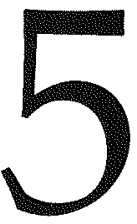

\title{
Party cooperation and the electoral system in Mauritius
}

\section{Raj Mathur}

The tiny Republic of Mauritius, of an area of $1,865 \mathrm{sq} \mathrm{km}$ and a population of 1.1 million, is situated in the Indian Ocean, $850 \mathrm{~km}$ east of Madagascar. It was first successfully colonised by the French (1715-1810) then by the British (1810-1968). On 12 March 1968 Mauritius became a sovereign democratic state but chose to keep the British Queen as the Head of State, represented in Mauritius by a Governor-General. Exactly 24 years after independence from Britain (on 12 March 1992), Mauritius became a republic, thus breaking one of the last umbilical links with Britain.

The Republic of Mauritius is a parliamentary democracy based on the Westminster model. It is one of the rare former British colonies which has retained the political system inherited from colonial times, 27 years after her independence and five years after becoming a republic. Of course, the Westminster model (winner-takes-all), had to be adapted to ensure power-sharing, a sine qua non for the survival and growth of multi-ethnic societies.

Before power-sharing amongst the various ethnic groups could become a reality in Mauritius, the country underwent some traumatic experiences in the 1950s and 1960s, the pre-independence period. Hence, we see the pertinence of the Mauritian experience to the Fijian problem. Successive constitutional conferences ${ }^{1}$ held in 
London before independence were preoccupied with devising an electoral system for Mauritius which would ensure the following conflicting goals

- a safe and adequate representation of the various ethnic groups comprising the Mauritian people

- majority rule but at the same time respect for the rights of the minorities.

These goals were to be reconciled by

- encouragement of voting which would cut across ethnic lines

- inter-party, and therefore, inter-ethnic collaboration at the level of government

- the imperative of power-sharing amongst the various parties, thus killing any notion of politics as a zero-sum game

- the growth of 'national parties', that is, parties which would represent the interests of all the various ethnic groups and would, therefore, necessarily seek genuine cross-ethnic support.

The Mauritian social structure is not dissimilar to Fiji's. Mauritius is a multi-ethnic, multi-lingual, multi-religious and, therefore, multicultural society. However, there is one major difference-while the Mauritian population is totally an immigrant one, Fiji has an indigenous population. Mauritius was first peopled in the 18th and early 19th centuries by African slaves to labour in the sugar plantations and to work in the households of the French and British colonisers. Following the abolition of slavery in 1835, French sugar magnates turned to the Indian subcontinent for labourers to work in the sugarcane fields. By 1881 the Indian immigrants and their dependants already constituted two-thirds of the inhabitants of Mauritius. $^{2}$

\section{The different communities}

According to the Constitution of Mauritius

The population of Mauritius shall be regarded as including a Hindu community, a Muslim community, and a Sino-Mauritian community, and every person who does not appear, from his way of life, to belong to one or other of those three communities shall be regarded as belonging to the General Population, which shall itself be regarded as a fourth community. ${ }^{3}$ 
Thus, there are only four main communities. The weight of each community, as a percentage of the total population is as follows ${ }^{4}$

$\begin{array}{lr}\text { Hindu } & 50.3 \text { per cent } \\ \text { Muslim } & 16.1 \text { per cent } \\ \text { General Population } & 30.7 \text { per cent } \\ \text { Chinese } & 2.9 \text { per cent }\end{array}$

It is significant to note that if the Hindu population is added to that of the Muslim, the weight of the population of Indian descent is 66.4 per cent.

There are divisions inside each of the four communities. The Hindus are divided along caste, religious and linguistic lines. There are several linguistic groups within the Hindu community: Telegu, Marathi, Tamil, Hindu and also many castes, such as Brahmin, Babouji, Vaish, and Rajput. There have always been attempts by extremist politicians to foster divisions by encouraging each one of the subgroups to demand parliamentary representation commensurate with its numerical strength. The extremists claim that Marathis, Telegus and Tamils should not be categorised as Hindus, that their cultural rites are different and that they have different religious traditions. Like the Hindu community, the Muslim community is also divided along caste, linguistic, economic lines but probably in a less pronounced form. The General Population for its part consists of Franco-Mauritians (less than one percent of the population), persons of mixed blood (Europeans and Africans, Europeans and Indians, Africans and Indians), and persons of African and Malagasy descent. The General Population is further divided along colour, social status and class lines. The Chinese community is also divided along religious (Xian or Buddhists), economic (big business or small shopkeepers), and political (Communist or Nationalist) lines.

\section{Parties and ethnicity in the 1950s and 1960s}

In the 1950s and 1960s the Mauritius Labour Party, which controlled a majority in the legislature and which had cross-communal support, rightfully claimed to be a national party, representing the interests of the various ethnic groups. The Opposition party, the Parti Mauricien Social Democrat (PMSD) which overtly claimed to represent the 
interests of the minorities-that is the Muslims, the Chinese, and, lastly but most importantly, the General Population-pressed for a system of Proportional Representation to ensure that the 'minorities' would have seats in the legislature, proportionate to their numerical strengths in the country. The opponents of the Mauritius Labour Party taxed the party for being communal, defending only the interest of the Hindu community. The Mauritius Labour Party, founded in 1936, preached class warfare in the late 1930s and 1940s against the sugar oligarchy. The party successfully aroused the class consciousness of the workers and was able to rally under its umbrella workers of all denominations and ethnic groups to press for a better deal with the sugar barons-mainly white Franco-Mauritians-in order to improve their desperately low living and working conditions. It became a major political force in the late 1930s and pressed for an extension of the vote to the working classes.

Fearing that political power would slip from their hands if the workers remained united, the sugar oligarchy instilled the poison of communalism to divide and arrest the working class movement. This is how politics became communal and ethnically based in the 1950 s and 1960s. Since the PMSD claimed to represent the minorities, the Mauritius Labour Party (already perceived by the population as being pro-Hindu) ${ }^{5}$ had no alternative but to turn to the latter to consolidate its votes. In the 1960s while the Labour Party and other progressive forces pressed for the Independence of Mauritius, the PMSD-representative of the minorities-demanded an Integration or Association with Britain, ostensibly because of their fear of Hindu hegemony after independence. The propaganda of the PMSD against Hindu domination scared the minorities, and led to an exodus of its population just before and after independence to Britain, France, and Australia. Fifty-four per cent of the population voted in favour of independence (that is, for the Labour Party and its allies) in the critical election of August 1967, while 44 per cent of the population (mostly people belonging to the General Population) voted for the PMSD, against independence (Mathur 1991:268).

From independence onwards both major parties made a big effort to become 'national', that is, embracing all ethnic groups. The PMSD accepted the offer of Sir Seewoosagur Ramgoolam, the Labour leader and Prime Minister, to join a government of national unity in 1969. 


\section{The electoral system}

Throughout the 1950 s and 1960 s, the electoral system and the mode of election to the legislature was the main bone of contention between the two main parties. Successive constitutional conferences held in London were haunted by the need to ensure a 'safe and adequate representation' to all sections of the Mauritius community. It is undoubtedly an achievement that this 'safe and adequate representation' has been made possible without the imposition of a Proportional Representation system which would probably have polarised the divisions along communal, caste and linguistic lines, thus rendering the process of nation-building more difficult.

For the purpose of elections to the National Assembly the country is divided into 21 constituencies, 20 for mainland Mauritius and 1 for Rodrigues (a smaller island). Each constituency in Mauritius elects three representatives whereas Rodrigues elects two representatives to the legislature. ${ }^{6}$ The present electoral boundaries of the various constituencies of Mauritius were drawn by British electoral experts in pre-independence days, to ensure 'adequate representation' to the two most important sections of the Mauritian population, namely the Hindus and the General Population. Ten constituencies are in the rural areas where Hindus predominate with the remaining ten in the urban areas. ${ }^{7}$ Thus the Hindus who constitute 50 per cent of the population would get adequate representation if, as has always been the practice, the national parties would field Hindu candidates in the rural areas. The General Population which constitutes 30 per cent of the population is the most important 'ethnic group' 8 in the majority of the urban constituencies. With the support of the other minority groups, it can muster a majority in urban constituencies, ensuring that it would always get a fair number of seats. Like the Hindu community, it would get 'adequate' representation in the National Assembly.

There is, however, a problem regarding the representation of the remaining two communities, the Muslim (16 per cent) and the Chinese (three per cent). National political parties do sponsor Muslim candidates in areas where that community constitutes a sizeable section of the population and one or two Chinese candidate(s) in a Port Louis constituency where the Chinese 
represent an important ethnic group. ${ }^{9}$ Parties, however, go much further in their choice of candidates for particular constituencies. They do not merely look at the ethnic configuration of a constituency but also consider the sub-groups-caste, cultural and linguistic appurtenance-of the voters, ensuring in the process that the several caste, cultural and linguistic groups of the Hindu community would be represented in the Legislature.

The electoral system is based on the Westminster First-Past-thePost system (FPP) with the important difference that whereas Britain has some 659 single-member constituencies, Mauritius has 20 threemember constituencies. It is a simple majority system. Candidates do not require an absolute majority ( 50 per cent of the votes +1 ) to be elected. The first three candidates, regardless of the percentage of votes obtained, are declared elected.

\section{Distortions caused by FPP}

Under the one-round elections prevalent in Mauritius, a party with only 35 per cent of the vote evenly distributed may get, in a threeparty contest, a majority of seats in Parliament. In theory that party may even get 100 per cent of the seats, if the strength of the other two parties are 33 and 32 per cent in every one of the 20 constituencies. At the 1982 elections the Mouvement Militant Mauricien/Parti Socialiste Mauricien alliance obtained 100 per cent of the seats with 64 per cent of the vote (see Mathur 1991:282). The 33 per cent of the electorate who voted for the Opposition had no representative at all in the Legislature. The Opposition was completely wiped out, thus jeopardising the workings of the British-based parliamentary system..$^{10}$ However the legitimacy of the Government was not challenged as it had the support of 64 per cent of the population. One may wonder what would have happened had total victory for one party or party alliance come with less than 50 per cent of the vote!

General elections were again held in 1983 and this time the winning alliance obtained 52 per cent of the vote and 41 of the seats (out of 60) that is, 68 per cent of the seats, leaving the Opposition with 19 seats ( 32 per cent) for 46 per cent of the vote. In 1987 the winning alliance with slightly less than 50 per cent of the vote obtained 65 per cent of the seats. In 1991 again the distortion was more pronounced, the winning alliance obtaining 95 per cent of seats for 56 per cent of the vote, leaving the Opposition with only 5 per 
cent of seats for 40 per cent of the vote. However the distortions were to become alarming when at the 1995 election, the winning alliance, repeating the performance of 1982, won all the seats for 65 per cent of the vote, leaving the Opposition, smaller parties and Independents with no seats at all for 35 per cent of the vote!

\section{Table 5.1: Votes and seats in General Elections, 1982-1995}

$\begin{array}{clcc}\text { General Elections } & \text { Alliance } & \% \text { Vote } & \text { \% Seat } \\ 1982 & \text { MMM/PSM } & 64 & 100 \\ & \text { LAB/PMSD } & 33 & - \\ 1983 & \text { MSM/LAB/PMSD } & 52 & 68 \\ & \text { MMM } & 46 & 32 \\ 1987 & \text { MSM/LAB/PMSD } & 50 & 65 \\ & \text { UNION } & 48 & 35 \\ 1991 & \text { MSM/MMM } & 56 & 95 \\ & \text { LAB/PMSD } & 40 & 5 \\ 1995 & \text { LAB/MMM } & 65 & 100 \\ & \text { MSM/Others } & 35 & -\end{array}$

Notes

1. The two seats of Rogrigues are normally contested by Rodriguan parties and are, therefore, not included.

2. MMM: Mouvement Militant Mauricien, founded in 1969 and led since its foundation by Paul Berenger.

3. PSM: The Parti Socialiste Mauricien a party founded by H. Boodhoo in 1979. The party is now defunct.

4. LAB: the Mauritius Labour Party founded in 1936 and at present led by Navin Ramgoolam, Prime Minister (Dec 1995-to date).

5. PMSD: the Parti Mauricien Social Democrates led by Sir Gaëtan Duval from 1966 until his death in 1996. At present the party is led by Sir Gaëtan's brother Hervé Duval.

6. MSM: the Mouvement Socialiste Militant was founded in 1983. It was the ruling party from March 1983 to December 1995. It is led by Sir Anerood Jugnauth, Prime Minister from 1982 to 1995 (1982 as the MMM party leader, then from 1983 as leader of the MSM).

7. UNION: the official name of the alliance of MMM along with two small political formations namely, the Mouvement Travailleurs Democrates, led by A. Baichoo and the FTS, the Front Travailleurs Socialiste, led by S. Michel.

8. Others: include the very small political formations and the Independents. At the 1987 elections, the MSM/LAB/PMSD alliance won 65 per cent of the seats with only 49.6 per cent of the vote. The figure has been rounded up to 50 per cent.

Under FPP, a small swing from one party to another may lead to a disproportionate percentage of seats changing hands. If this is true 
for countries with single-member constituencies, the distortion between the percentage swing in votes and seats may be three times as much in a country like Mauritius where the three-member constituencies prevail (see Rae 1971). In 1983 the results were so clear-cut with the winning alliance obtaining an average of 64 per cent in practically all constituencies, that it would have required an enormous swing from the winning party to the losing alliance for seats to change hands. In 1987 a four per cent swing in favour of the losing alliance and against the winner would have meant that the losing alliance would have obtained 37 seats with 50 per cent of the vote and, therefore, form the Government! In 1987 the losing side would have gained office with only two per cent swing in its favour against the winner. It would have obtained 32 out of the 60 seats $!^{11}$

Political parties, with the exception of the ruling Labour Party, are seriously considering a mixed system which would incorporate FPP and a form of Proportional Representation.

\section{Best losers}

Over and above the direct election of 62 members to the National Assembly, the Constitution of Mauritius also provides for the allocation of eight additional seats to ensure a 'fair and adequate representation' of each community. ${ }^{12}$ These additional seats are known as 'Best Loser' seats. Thus, the Mauritian Parliament is made up of seventy members -62 directly-elected (60 in Mauritius and 2 in Rodrigues) and eight Best Losers. The first four Best-Loser seats are allocated to under-represented communities (resulting from the results of the direct elections) regardless of the candidates' political affiliations. However the candidates must obtain the highest score amongst other defeated candidates belonging to the same community. The under-represented community is determined by dividing the number of persons belonging to that community by the number of seats that the community has obtained plus one. The community with the highest quotient is the appropriate community and MPs belonging to that community represent a greater number of persons than MPs belonging to other communities. A separate exercise is done for each seat to determine the under-represented community.

The second set of four Best Losers is awarded on a party and community basis. The emphasis is first on party because the balance 
of political power which existed soon after the general election must not be offset. In a close election, if such a rider were not laid down, the Opposition might become the majority party by winning a greater number of Best Loser seats. The candidates chosen must belong to the under-represented community. However the score obtained by candidates must be the highest in relation to other candidates of their party belonging to their community.

Following the 1982 and 1995 elections there has been a massive popular movement in favour of the abolition of the Best Loser system, and therefore doing away with the vestiges of communalism in Mauritian politics. It is argued that the electorate in the successive elections held from 1976 to 1995 did not vote along communal lines. Instead the electorate's choice was more motivated by the program of the parties, the competence of the team presented by the various parties, the choice of a Prime Minister, political principles and ideology rather than by race, caste or religion. The movement contends that it is high time for the Mauritian Parliament to pass a Bill abolishing the constitutional provisions for Best Loser seats. This would in effect mean the abolition of formal ethnic representation and, hopefully, put an end to ethnically based politics.

\section{Party cooperation and sharing of political power}

The Mauritian electoral system encourages bipolarisation of the political system. The FPP favours the formation of two major political alliances confronting each other. A third party, or still less smaller political formations, has no chance at all to have their candidates elected unless the support is concentrated in one or two constituencies. There is either a pre-electoral alliance of two parties perceived by the population as representative of the two major ethnic groups (Hindus and General Population) or a post-electoral coalition formed by parties perceived as representatives of the two major ethnic groups after the election results are known. There is, therefore, a real sharing of political power by all the different constituents of the Mauritian nation. This sharing of political power ensures that the several ethnic groups and sub-groups have their share of the national cake, in particular the appointment to top positions in the civil service, parastatal bodies, municipalities, and in the private sector.

Since independence, Mauritius has been governed by a coalition formed after the results of the elections are known or by an alliance 
concluded before the elections. It is conceded that no party on its own can expect to win a parliamentary majority. Pre-election alliances and coalition governments are the rule. Politics in Mauritius has never been conceived as a zero-sum game.

Democracy in multi-ethnic societies does not merely mean majority rule, governing with 50 per cent plus 1 seats. Rather it means a readiness to share political power with other parties which are perceived to be representatives of other communal or ethnic interests. All the important communal, linguistic and economic groups must be represented in Parliament and in the Cabinet. Since the introduction of the Ministerial system in 1958, the British colonial power had assured that the governments formed were governments of national unity, encompassing all the various ethnic groups and political parties. ${ }^{13}$ Successive governments formed after independence have always consisted of ministers from all the major ethnic groups.

In their bid to win political power, the two major parties strove very hard to be perceived by the electorate as 'national' parties. They would field candidates from all the major communities. These candidates are not 'puppets' but rather important personalities capable of seeking and obtaining cross-communal support. The main political parties in Mauritius have learnt a very important lessonnamely that to win political power a party cannot be perceived as being solely ethnically based, defending the interests of only one community. Rather it must obtain cross-communal support. This stark reality has sunk so much in the minds and hearts of the political élite that today there is no major party which is ethnically based. All the major parties can claim to be truly national parties.

\section{Notes}

1. These constitutional conferences were convened by the colonial power to pave the way for self-government and eventual independence.

2. In 1881 there were 249,064 Indians out a total population of 360,847 (Mauritius 1891:1:7).

3. Schedule 1, para 3(4) of the Constitution.

4. The population figures, from which the percentages have been worked out, are based on the 1972 population census-the last 
census when the population was required to indicate their communal appurtenance. There has not been any significant change in the ethnic distribution of the population (Ministry of Economic Planning and Development 1974).

5. Up to the end of the 1950s, the Mauritius Labour party was supported by workers of all denominations. The Parti Mauricien Social Democrat's propaganda that the Labour Party was a proHindu party was successful in convincing the non-Hindu 'minorities' only in the 1960s.

6. Schedule 1, para 1 (1) of the Constitution of Mauritius.

7. See Trustram-Eve Report in Sessional Paper 1 of 1958, Report of the Mauritius Electoral Boundary Commission and also the Banwell Report in Sessional Paper 5 of 1966, Government of Mauritius, Port Louis, Mauritius.

8. However, the Community General Population has an absolute majority in only one constituency.

9. This practice which encourages inter-ethnic collaboration was initially recommended by the British Electoral Commissioner Trustram-Eve in 1958. It has since then been followed scrupulously.

10. The allocation of 4 seats to the Opposition through the Best Loser system provided a skeletal parliamentary opposition.

11. For the effect of swings, see Mathur 1991.

12. Schedule 1, para 5 to the Constitution of the Republic of Mauritius.

13. During the colonial era, it was the British Governor who formed the Council of Ministers. He appointed as ministers persons whom he considered to be representatives of the various communities. These appointments would be carried out regardless of whether the appointees were elected members or nominees of the then Legislative Council.

\section{References}

Mathur, Hansraj, 1991. Parliament in Mauritius, Editions de l'Océan Indien, Rose Hill.

Mauritius, 1992. The Constitution of the Republic of Mauritius, Port Louis.

Ministry of Economic Planning and Development, 1974. Mauritius Population Census of 1972, Port Louis. 
State, society and governance in Melanesia

Mauritius 1891, Census of Mauritius and its Dependencies April 1891, Port Louis.

Rae, Douglas W., 1971. The Political Consequences of Electoral Laws, Yale University Press, New Haven. 